\title{
Small interfering RNA directed against microRNA-155 delivered by a lentiviral vector attenuates asthmatic features in a mouse model of allergic asthma
}

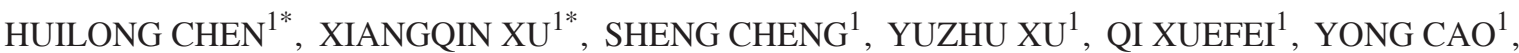 \\ JUNGANG XIE $^{1}$, CONG-YI WANG ${ }^{2}$, YONGJIAN XU ${ }^{1}$ and WEINING XIONG ${ }^{1}$ \\ ${ }^{1}$ Department of Respiratory and Critical Care Medicine; ${ }^{2}$ Center for Biomedical Research, Tongji Hospital, Tongji \\ Medical College, Huazhong University of Science and Technology, Wuhan, Hubei 430030, P.R. China
}

Received October 26, 2016; Accepted June 15, 2017

DOI: $10.3892 /$ etm.2017.5093

\begin{abstract}
Asthma is a chronic $\mathrm{T}$ helper type 2 (Th2) cell-mediated inflammatory disease characterized by airway hyperresponsiveness (AHR) and airway inflammation. Although the majority of patients with asthma can achieve a good level of control with existing treatments, asthma runs a chronic course and the effectiveness of current treatment is not satisfactory for certain patients. MicroRNAs (miRNAs) are short noncoding RNAs that suppress gene expression at the post-transcriptional level; their role in regulating allergic inflammation remains largely unknown. The present study aimed to explore the role of miRNA-155 in the pathogenesis of asthma and its potential as a target for treatment. The expression of miRNA-155 increased in ovalbumin-sensitized and challenged mice compared with control mice, and lentiviral vector-delivered small interfering (si)RNA targeting miRNA-155 resulted in reduced AHR, airway inflammation and Th2 cytokine production. The data from the present study indicate that miRNA-155 serves an important role in the pathogenesis of asthma, and that lentiviral vector-delivered siRNA targeting miRNA-155 may serve as a novel approach for the treatment of allergic asthma.
\end{abstract}

\section{Introduction}

Asthma is a common chronic airway inflammatory disease characterized by $\mathrm{T}$ helper 2 (Th2) cell-mediated eosinophilic

Correspondence to: Dr Weining Xiong, Department of Respiratory and Critical Care Medicine, Tongji Hospital, Tongji Medical College, Huazhong University of Science and Technology, 1095 Jiefang Avenue, Wuhan, Hubei 430030, P.R. China

E-mail: xiongdoctor@hotmail.com

*Contributed equally

Key words: asthma, gene therapy, microRNA, microRNA-155, lentivirus, small interfering RNA inflammation and airway hyperresponsiveness (AHR) (1). The World Health Organization estimates that as many as 300 million people worldwide suffer from asthma (2). Despite intense ongoing research, the underlying molecular mechanisms leading to asthma remain unclear. Although the majority of patients with asthma can achieve a good level of control with existing treatments, asthma still has a chronic and long disease course, and the effectiveness of current treatments is not satisfactory for numerous patients.

MicroRNAs (miRNAs/miRs) are a large family of endogenous noncoding RNAs that post-transcriptionally modulate gene expression by promoting mRNA degradation or inhibiting protein translation (3). The alteration of miRNA expression has been implicated in a range of human diseases (4-6). Emerging evidence has identified that miRNAs serve an essential role in allergic airway diseases. Inhibition of miR-126 was demonstrated to suppress the function of Th2 cells and the development of allergic airway inflammation (7). In addition, antagonism of miR-145 has been revealed to inhibit eosinophilic airway inflammation, Th2 cytokine production and AHR (8). Furthermore, another previous study identified that anti-let-7 treatment markedly inhibited the production of allergic cytokines and asthmatic features (9). Based on the aforementioned evidence, the manipulation of miRNA expression has a potential application for the treatment of allergic airway diseases.

Attention has recently been focussed on to miR-155, a multifunctional miRNA, due to its role in multiple physiological processes in the immune system (10-13). Data from clinical samples support the theory that miR-155 serves a critical role in the pathogenesis of allergic diseases, including allergic rhinitis $(14,15)$ and atopic dermatitis (16). In regards to the lungs, mice deficient in miR-155 exhibited enhanced airway remodelling (12) and miR-155 was demonstrated to contribute to the regulation of allergic airway inflammation by modulating Th2 responses through the transcription factor PU.1 (17). In addition, miR-155 deficiency has been identified to alleviate allergic airway inflammation in mice (18). Despite limited evidence linking miR-155 to the etiology of asthma, previous studies have evaluated the feasibility of using miR-155 antagonists to treat asthma $(19,20)$. 
The present study indicates that miR-155 serves an important proinflammatory role in the development of AHR and allergic airway inflammation. Decreasing the level of miR-155 with small interfering (si)RNA delivered by a lentiviral vector significantly reduced the severity of inflammatory lesions and AHR. These findings suggest that a siRNA-expressing lentiviral vector targeting miR-155 may be a novel approach for the therapy of asthma.

\section{Materials and methods}

Mice. A total of 24 female BALB/c mice (weight, 18-20 g; 4-6 weeks old) were purchased from the Laboratory Animal Center of Hubei Province (Wuhan, China). All mice were maintained in a vinyl isolator in a room maintained at a constant temperature $\left(22 \pm 2^{\circ} \mathrm{C}\right)$ and humidity $(55 \pm 5 \%)$ on a 12-h light/dark cycle. Mice were provided with water and food ad libitum. The Institutional Animal Care and Use Committee of Tongji Hospital (Wuhan, China) approved the protocols used for animal experiments in the present study.

Construction of short hairpin (sh)RNA and cloning of shRNAs into lentiviral vectors. The sequence of the miR-155-targeting complementary shRNA was 5'-TACCCCTATCACAAT TAGCATTAA-3'. The negative control shRNA used was part of a Lenti-KD Custom RNAi commercial kit provided by Shanghai GeneChem Co., Ltd. (Shanghai, China). Third-generation human immunodeficiency virus-1-derived lentiviral vector stocks, pseudotyped with the vesicular stomatitis virus envelope glycoprotein $\mathrm{G}$, were produced as previously described $(21,22)$. shRNA lentiviral vectors were produced by calcium phosphate-mediated transient transfection of HEK 293T cells (Shanghai GeneChem Co., Ltd. Shanghai, China). Briefly, HEK 293T cells were cultured in DMEM supplemented with $10 \% \mathrm{FBS}$ in $5 \% \mathrm{CO}_{2}$ at $37^{\circ} \mathrm{C}$ a humidified atmosphere and $5 \times 10^{6}$ cells seeded in $100-\mathrm{mm}$ dishes were cotransfected with Lenti-Easy Packaging Mix $(25 \mu \mathrm{l}, 1 \mu \mathrm{g} / \mu \mathrm{l})$ and GFP Control Plasmid $(20 \mu \mathrm{l}, 0.8 \mu \mathrm{g} / \mu \mathrm{l})$ (Shanghai GeneChem Co., Ltd. Shanghai, China). The viruses were collected and concentrated 100 -fold by ultracentrifugation $\left(4^{\circ} \mathrm{C}\right.$ at 4,000 $\mathrm{x}$ g for $\left.30 \mathrm{~min}\right)$. The concentrated virus stocks were titered in $5 \times 10^{4}$ cells $/ \mathrm{ml}$ HEK $293 \mathrm{~T}$ cells at $37^{\circ} \mathrm{C}$ for $72 \mathrm{~h}$ based on green florescent protein (GFP) expression.

Generation of asthma model and lentiviral vector transduction in vivo. To generate an asthmatic model (6 mice per group), mice were sensitized and challenged with ovalbumin (OVA) as previously reported (23). The mice were immunized intraperitoneally on day 0 and 14 with $100 \mu \mathrm{g}$ OVA (S7951; Sigma-Aldrich; Merck KGaA; Darmstadt, Germany) and $1 \mathrm{mg}$ aluminium hydroxide (77161; Thermo Fisher Scientific, Inc., Waltham, MA, USA) in $200 \mu \mathrm{l}$ of $0.9 \%$ saline. The mice were then challenged by intratracheal administration of $200 \mu \mathrm{g}$ OVA in $20 \mu \mathrm{l}$ saline on days 22,23 and 24. Solutions at $4 \times 10^{7}$ titer units (TU)/ml containing $50 \mu \mathrm{l}$ of the negative control lentivirus or the miR-155 shRNA lentivirus ( $\left.4 \times 10^{7} \mathrm{TU} / \mathrm{ml}, \sim 2 \times 10^{6} \mathrm{TU} / \mathrm{mouse}\right)$ were delivered intratracheally 3 days prior to the first challenge with OVA. Scrambled miR-155 shRNA and miR-155 shRNA lentiviral vectors contained a sequence encoding GFP. Transduction efficiency was assessed via florescence microscopy (magnification, x100).

Reverse transcription-quantitative polymerase chain reaction $(R T-q P C R)$ analysis. Total RNA was extracted from lung tissue using TRIzol (Invitrogen; Thermo Fisher Scientific, Inc., Waltham, MA, USA). cDNA was synthesized with a miRNA-specific primer using the Fermentas First-Strand Synthesis kit (SuperScript III First-Strand Synthesis SuperMix for qRT-PCR; Thermo Fisher Scientific, Inc.) according to the manufacturer's protocol. qPCR was performed to determine miR-155 expression and U6 was used as the internal control, as previously described (24). All primers used were provided by Guangzhou RiboBio Co., Ltd. (mir-155, miRQ0000165-1-2; U6, MQP-0201, Guangzhou, China). The primers sequences were not released. Thermocycling was performed as follows: $60 \mathrm{~min}$ at $42^{\circ} \mathrm{C}$ and $5 \mathrm{~min}$ at $70^{\circ} \mathrm{C}$ for reverse transcription and denaturation, respectively, followed by 40 amplification cycles consisting of $95^{\circ} \mathrm{C}$ for $5 \mathrm{sec}$ (denaturation) and $60^{\circ} \mathrm{C}$ for $30 \mathrm{sec}$ (extension). The $2^{-\Delta \Delta C q}$ method (25) was applied to calculate relative quantification of miRNA expression.

Measurement of AHR. A total of $24 \mathrm{~h}$ after the last challenge, AHR was measured using a computer-controlled small animal ventilator system (flexiVent; SCIREQ Scientific Respiratory Equipment, Inc., Montreal, Canada) as described by Kramer et al (26). Mice were anesthetized by intraperitoneal injection of pentobarbital sodium $(70-90 \mathrm{mg} / \mathrm{kg}$; Sigma-Aldrich; Merck KGaA, Darmstadt, Germany), tracheostomized with an 18-gauge cannula and mechanically ventilated in a quasi-sinusoidal fashion with a small animal ventilator at a frequency of $2.5 \mathrm{~Hz}$ and a tidal volume of $12 \mathrm{ml} / \mathrm{kg}$. The airway resistance values $\left(\mathrm{R}_{\mathrm{aw}} ; \mathrm{cm} / \mathrm{H}_{2} \mathrm{O} . \mathrm{sec} / \mathrm{ml}\right)$ were recorded in response to increasing doses of nebulized methacholine $(0,3,6,12,25 \mathrm{mg} / \mathrm{ml})$ (Sigma-Aldrich; Merck $\mathrm{KGaA}$ ). Results were expressed for each concentration of methacholine as a percentage of the $0 \mathrm{mg} / \mathrm{ml}$ methacholine $\mathrm{R}_{\text {aw }}$ value after exposure to PBS.

Collection of bronchoalveolar lavage fluid (BALF) and histological analysis. Mice were sacrificed $24 \mathrm{~h}$ after the last OVA or saline challenge. The lungs were lavaged three times with $0.8 \mathrm{ml}$ of saline, and the collected cells were centrifuged $\left(4^{\circ} \mathrm{C}\right.$ at $300 \mathrm{x} \mathrm{g}$ for $\left.10 \mathrm{~min}\right)$ and subjected to Wright-Giemsa staining as previously reported (27). A number of differential cell counts, including eosinophils, macrophages, lymphocytes and neutrophils, were performed on total of 200 cells based on the staining of characteristics of morphology, as previously described (28). Supernatant samples were collected for cytokine assays. The left lungs were isolated and fixed in $4 \%$ paraformaldehyde at room temperature for $24 \mathrm{~h}$, and then embedded in paraffin. Subsequently, $5-\mu \mathrm{m}$-thick sections were stained using hematoxylin and eosin (H\&E) and observed under a light microscope (magnification, x200).

ELISA. Interleukin (IL)-4, IL-5 and IL-13 levels in BALF were quantified by ELISA (EMC003.48, EMC108.48 and EMC124.48; Neobioscience, Beijing, China) according to the manufacturer's protocol. 
Statistical analysis. Data are presented as the mean \pm standard error of the mean. Data were analyzed with GraphPad Prism software 5.1 (GraphPad Software, Inc., San Diego, CA, USA). Two-way analysis of variance followed by Bonferroni's post hoc test was used for the comparison of multiple groups. $\mathrm{P}<0.05$ was considered to indicate a statistically significant difference.

\section{Results}

miRNA-155 expression is upregulated in mice with OVA-induced asthma and miR-155 expression is successfully silenced by intratracheal instillation of the anti-miR-155 shRNA lentiviral vector in vivo. The miR-155 expression level in the lungs of the OVA-sensitized and challenged mice was significantly increased compared with that in the saline challenged mice $(\mathrm{P}<0.01$; Fig. 1A). After treatment with the miR-155 shRNA lentiviral vector, miR-155 expression was significantly decreased compared with the OVA group and the negative control shRNA group (the mock group) (both $\mathrm{P}<0.01$; Fig. 1A). Transduction efficiency was also assessed by detecting the expression of the marker gene, GFP (Fig. 1B). The findings indicated that the transfection efficiency of lentiviral vector was good.

Delivery of the miR-155 shRNA lentiviral vector before airway challenge prevents the development of allergic airway inflammation. The miR-155 shRNA or the negative control shRNA lentiviral vector were intratracheally administered $72 \mathrm{~h}$ before the first OVA challenge in order to determine the effects of the miR-155-taregting shRNA lentivirus on airway inflammation. Notably, miR-155 shRNA lentiviral vector administration significantly reduced the total cell count of eosinophils, macrophages and lymphocytes count in the BALF after OVA sensitization and challenge $(\mathrm{P}<0.01$ vs. the OVA and mock groups), whereas the negative control shRNA lentivirus treatment did not significantly decrease the cell counts compared with the OVA group (Fig. 2A). Evidence of inflammatory cell infiltration and the effects of the miR-155 shRNA lentiviral vector treatment were further investigated by histologically examining lung sections stained with H\&E. When compared with the mock group, miR-155 shRNA lentivirus treatment decreased inflammatory cells infiltration in the lung tissue (Fig. 2B).

AHR is inhibited by miR-155 shRNA lentivirus treatment. Administration of the miR-155 shRNA lentiviral vector was identified to attenuate the development of airway resistance as a reaction to increasing concentrations of inhaled methacholine. $\mathrm{R}_{\mathrm{aw}}$ was significantly decreased in the miR-155 shRNA group compared with the mock and OVA groups $(\mathrm{P}<0.01$; Fig. 3$)$.

Th2 cytokine expression in BALF decreases after intratracheal instillation of the miR-155 shRNA lentiviral vector. The expression of IL-4, IL-5 and IL-13 in the BALF was examined. The levels of IL-4, IL-5 and IL-13 were significantly upregulated in the OVA group compared with the saline group, and decreased significantly after treatment with miR-155 shRNA lentivirus compared with that of the OVA and mock groups (all $\mathrm{P}<0.01$; Fig. 4).

\section{Discussion}

The role of miRNAs in the pathogenesis of allergic asthma has been widely studied since $2007(7-9,12,16,29)$ and therapies that target miRNAs were considered to be important for further study $(30,31)$. The results of the present study indicate that miR-155 is associated with the development of allergic airway inflammation; miR-155 expression was significantly higher in the lungs of mice with asthma compared with normal controls. In addition, treatment with a miR-155-targeting shRNA lentiviral vector in vivo substantially alleviated airway inflammation and AHR due to miR-155 inhibition.

Previous microarray analysis has demonstrated that miR-155 is upregulated in OVA-induced mouse models of asthma (9,32). The present study confirmed that the expression of miR-155 was significantly increased in the lungs of mice with asthma by RT-qPCR. These data indicate that the upregulation of miR-155 is associated with the pathogenesis of asthma. Certain previous studies have revealed that higher miR-155 expression exists in the smooth muscle cells of asthmatic airways (33) and bronchial epithelial cells (34), which is partly consistent with the results of the present study. However, further exploration of the function of miR-155 in other cell types will be important to understand the role of miR-155 in the development of the allergic immune response.

Mice deficient in miR-155 have been reported to be protected against allergen-induced eosinophilic airway inflammation $(17,18)$. In the present study, an shRNA was applied as a therapeutic strategy to suppress miR-155 expression, which successfully reduced inflammation, infiltration of eosinophils, and the production of the Th2 cytokines IL-4, IL-5 and IL-13. In addition, miR-155-targeting shRNA inhibited AHR, another important feature of asthma (35). These results support the suggested role of miR-155 in the development of allergic airway inflammation. However, the precise mechanism by which miR-155 regulates AHR remains to be clarified. Interestingly, another group demonstrated that miR-155-deficient mice spontaneously exhibited airway remodelling (12). A possible explanation for the discrepancy between this study and the present study could be the different mouse model used. An acute asthma mouse model was employed in the present study, whereas in the study conducted by Rodriguez et al (12), aging mice were used. Airway remodeling may follow acute inflammation or begin insidiously as a low-grade smoldering response (36). It is unknown whether airway inflammation contributes to airway remodelling. Previous clinical data has demonstrated that anti-inflammatory treatment may have no effect on airway remodeling in patients with asthma $(37,38)$. These results suggest a paradoxical role of miR-155 in airway inflammation and airway remodeling, and support the complex role of miRNA in the development of asthma.

The knockdown of miRNA is an effective method to use when characterizing the functions of miRNAs in vivo. Antagomirs, chemically modified oligonucleotides complementary to individual miRNAs, are widely used to transiently inhibit miRNA function (39). However, this method has several limitations. It is difficult to directly measure the depletion of an miRNA, because the antisense oligonucleotide binds to the miRNA and sequesters it from its target rather than inducing its degradation. The lentiviral vector-mediated gene 


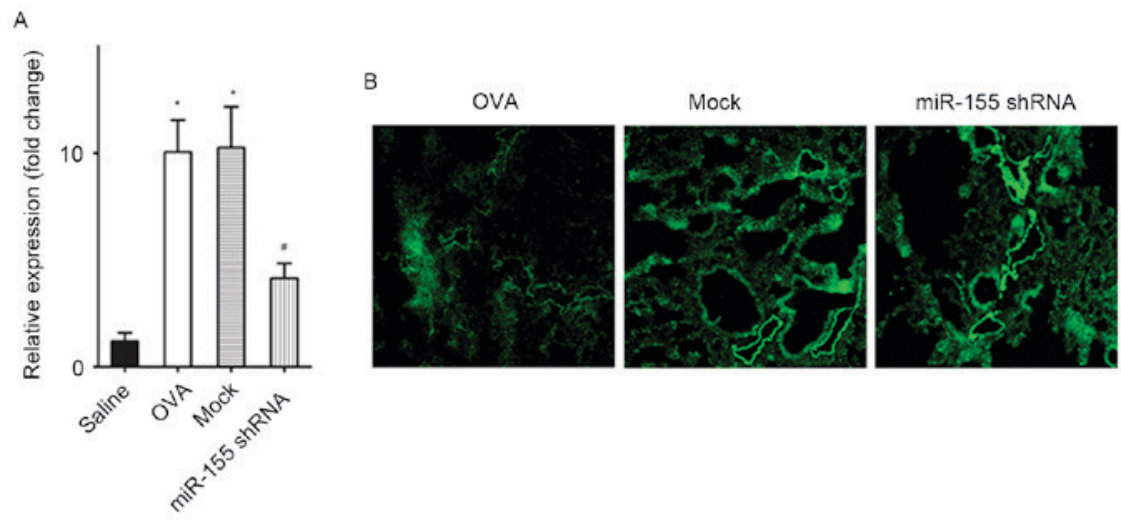

Figure 1. miR-155 expression is increased in mice with OVA-induced asthma and decreased after the administration of a miR-155 shRNA lentiviral vector in vivo. (A) Relative expression of miRNA-155 in mouse lungs. (B) Fluorescence microscopy of mouse lung sections (magnification, x100) after lentiviral vector exposure showing green fluorescent protein expression. $\mathrm{n}=4-6$ mice/group. ${ }^{*} \mathrm{P}<0.01$ vs. the saline group; ${ }^{\prime} \mathrm{P}<0.01$ vs. Mock group. OVA, ovalbumin; miR-155, microRNA-155; shRNA, short hairpin RNA; GFP, green florescent protein.

A

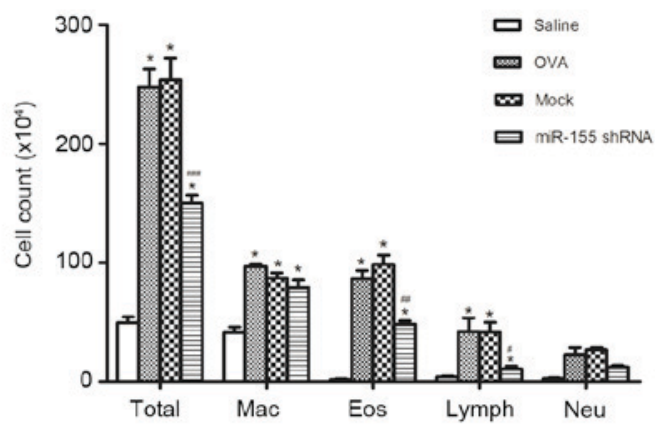

B

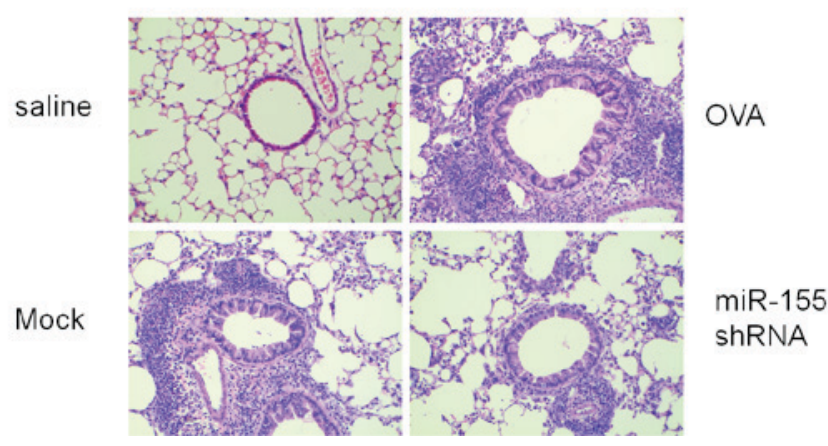

Figure 2. miR-155 shRNA lentiviral vector delivery attenuates airway inflammation after OVA challenge. (A) Differential cell counts for Mac, Eos, Lymph and Neu were calculated from cytospin preparations of bronchoalveolar lavage fluid collected $24 \mathrm{~h}$ after the last OVA challenge. (B) Histopathological sections of lungs collected $24 \mathrm{~h}$ after the last OVA challenge, and stained with hematoxylin and eosin (magnification, $\mathrm{x} 200$ ). $\mathrm{n}=5$ mice/group. ${ }^{*} \mathrm{P}<0.01$ vs. the saline group; ${ }^{\#} \mathrm{P}<0.05$, ${ }^{\# \#} \mathrm{P}<0.01$ and ${ }^{\# \# \#} \mathrm{P}<0.001$ vs. Mock group. Mac, macrophages; Eos, eosinophils; Lymph, lymphocytes; Neu, neutrophils; OVA, ovalbumin; miR-155, microRNA-155; shRNA, short hairpin RNA.

delivery system also has some advantages over antagomirs, including a high efficiency of gene transduction into a wide variety of cells, including dividing and non-dividing cells, and long-term infection $(40,41)$. Lentiviral vectors were used to knockdown miR-155, stably and specifically, in vivo. The lentivirus encoding miR-155 shRNA used in the present study successfully downregulated miR-155 expression. However, it

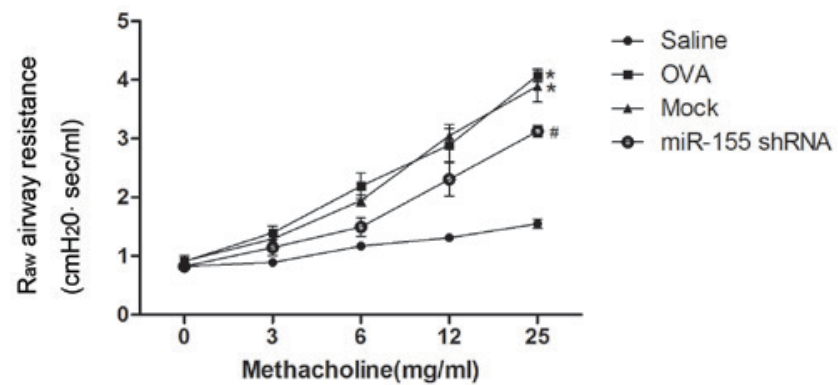

Figure 3. Delivery of miR-155 shRNA lentiviral vectors suppresses the development of airway hyperresponsiveness. Mice were exposed to nebulized saline, followed by increasing doses $(3-25 \mathrm{mg} / \mathrm{ml})$ of nebulized methacholine for $3 \mathrm{~min}$ each. Breathing indices were measured for $3 \mathrm{~min}$ after each nebulization and enhanced pause values were determined. $n=4-5$ mice/group. ${ }^{*} \mathrm{P}<0.01$ vs. the saline group; ${ }^{~} \mathrm{P}<0.05$ vs. Mock group. OVA, ovalbumin; miR-155, microRNA-155; shRNA, short hairpin RNA; $\mathrm{R}_{\mathrm{aw}}$, airway resistance.

was not clear what the target cells for anti-miR-155 were in the present study. A deficiency in miR-155 reduces cluster of differentiation $(\mathrm{CD}) 4^{+} \mathrm{T}$ cell activation and transcription factor expression in the lungs (17). In addition, miR-155 deficient dendritic cells (DCs) have been demonstrated to exhibit limited Th2 priming capacity and thus failed to induce airway inflammation (18). These results indicate that suppression of miR-155 expression, through anti-miR-155 treatment, in $\mathrm{CD}^{+}{ }^{+}$cells and/or DCs in vivo may contribute to the attenuation of asthmatic features in mouse models of asthma. Furthermore, other cell types, including bronchial epithelial cells and airway smooth muscle cells, may be target cells for anti-miR-155 treatment.

miRNAs are believed to function in vivo by targeting multiple functionally related proteins or a key protein target $(42,43)$. Several target genes for miR-155 have been identified, including transcription factor PU.1, activation-induced cytidine deaminase, suppressor of cytokine signaling 1 and inositol polyphosphate-5-phosphatase D $(44,45)$. Rodriguez et al (12) confirmed that MAF bZIP transcription factor was a direct target of miR-155 in T cells. However, in 

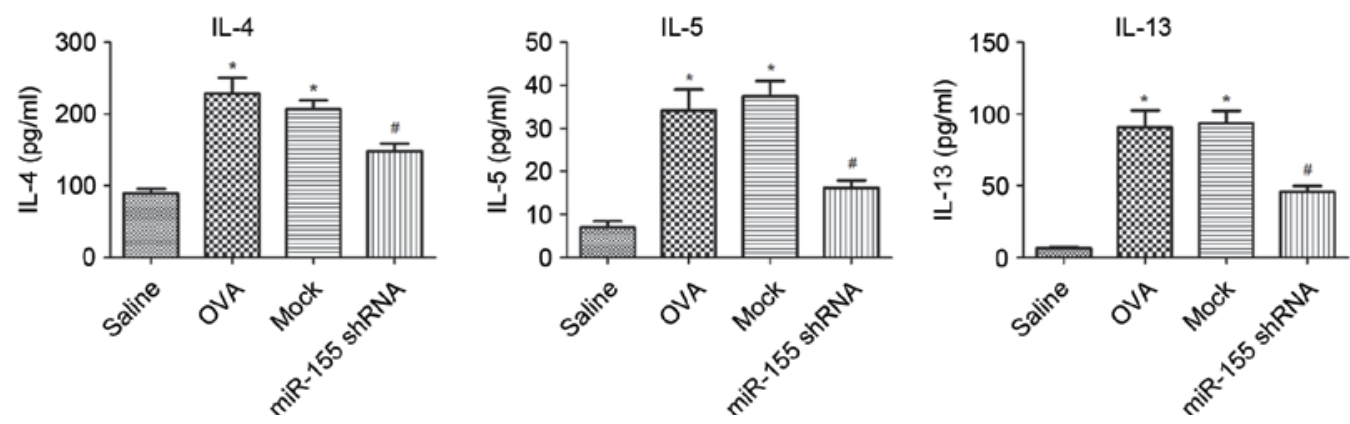

Figure 4. Silencing of miR-155 decreases cytokines levels in bronchoalveolar lavage fluid. IL-4, IL-5 and IL-13 concentrations in BALF were assessed by ELISA $24 \mathrm{~h}$ after the last OVA challenge. " $\mathrm{P}<0.01$ vs. the saline group; ${ }^{*} \mathrm{P}<0.01$ vs. the mock group. $\mathrm{n}=5-6 \mathrm{mice} / \mathrm{group}$. OVA, ovalbumin; miR-155, microRNA-155; shRNA, short hairpin RNA; IL, interleukin.

the present study, the proteins that were targeted by miR-155 were not identified.

In conclusion, the present study identified that miR-155 was significantly upregulated in an OVA-induced mouse model of asthma, and that inhibition of miR-155 using a lentiviral vector alleviated airway inflammation, AHR and Th2 cytokine release. These results highlight the important role of miR-155 in the pathogenesis of asthma and that miR-155 may serve as a novel target for the treatment of allergic inflammatory diseases.

\section{Acknowledgements}

The present study was supported by the National Natural Science Foundation of China (grant no. 81570024).

\section{References}

1. Barnes PJ: Immunology of asthma and chronic obstructive pulmonary disease. Nat Rev Immunol 8: 183-192, 2008.

2. Bousquet J, Mantzouranis E, Cruz AA, Aït-Khaled N, Baena-Cagnani CE, Bleecker ER, Brightling CE, Burney P, Bush A, Busse WW, et al: Uniform definition of asthma severity, control, and exacerbations: Document presented for the World Health Organization consultation on severe asthma. J Allergy Clin Immunol 126: 926-938, 2010.

3. Bartel DP: MicroRNAs: Target recognition and regulatory functions. Cell 136: 215-233, 2009.

4. Du C, Liu C, Kang J, Zhao G, Ye Z, Huang S, Li Z, Wu Z and Pei G: MicroRNA miR-326 regulates TH-17 differentiation and is associated with the pathogenesis of multiple sclerosis. Nat Immunol 10: 1252-1259, 2009.

5. Thum T, Gross C, Fiedler J, Fischer T, Kissler S, Bussen M, Galuppo P, Just S, Rottbauer W, Frantz S, et al: MicroRNA-21 contributes to myocardial disease by stimulating MAP kinase signalling in fibroblasts. Nature 456: 980-984, 2008.

6. Ma L, Teruya-Feldstein J and Weinberg RA: Tumour invasion and metastasis initiated by microRNA-10b in breast cancer. Nature 449: 682-688, 2007.

7. Mattes J, Collison A, Plank M, Phipps S and Foster PS: Antagonism of microRNA-126 suppresses the effector function of TH2 cells and the development of allergic airways disease. Proc Natl Acad Sci USA 106: 18704-18709, 2009.

8. Collison A, Mattes J, Plank M and Foster PS: Inhibition of house dust mite-induced allergic airways disease by antagonism of microRNA-145 is comparable to glucocorticoid treatment. J Allergy Clin Immunol 128: 160-167, 2011.

9. Polikepahad S, Knight JM, Naghavi AO, Oplt T, Creighton CJ, Shaw C, Benham AL, Kim J, Soibam B, Harris RA, et al: Proinflammatory role for let-7 microRNAS in experimental asthma. J Biol Chem 285: 30139-30149, 2010.

10. Lind EF and Ohashi PS: Mir-155, a central modulator of T-cell responses. Eur J Immunol 44: 11-15, 2014.
11. Vigorito E, Kohlhaas S, Lu D and Leyland R: miR-155: An ancient regulator of the immune system. Immunol Rev 253: 146-157, 2013.

12. Rodriguez A, Vigorito E, Clare S, Warren MV, Couttet $P$, Soond DR, van Dongen S, Grococ RJ, Das PP, Miska EA, et al: Requirement of bic/microRNA-155 for normal immune function. Science 316: 608-611, 2007.

13. Seddiki N, Brezar V, Ruffin N, Lévy Y and Swaminathan S: Role of miR-155 in the regulation of lymphocyte immune function and disease. Immunology 142: 32-38, 2014.

14. Suojalehto H, Lindström I, Majuri ML, Mitts C, Karjalainen J, Wolff $\mathrm{H}$ and Alenius $\mathrm{H}$ : Altered microRNA expression of nasal mucosa in long-term asthma and allergic rhinitis. Int Arch Allergy Immunol 163: 168-178, 2014.

15. Suojalehto H, Toskala E, Kilpeläinen M, Majuri ML, Mitts C, Lindström I, Puustinen A, Plosila T, Sipilä J, Wolff H and Alenius H: MicroRNA profiles in nasal mucosa of patients with allergic and nonallergic rhinitis and asthma. Int Forum Allergy Rhinol 3: 612-620, 2013.

16. Sonkoly E, Janson P, Majuri ML, Savinko T, Fyhrquist N, Eidsmo L, Xu N, Meisgen F, Wei T, Bradley M, et al: MiR-155 is overexpressed in patients with atopic dermatitis and modulates T-cell proliferative responses by targeting cytotoxic T lymphocyte-associated antigen 4. J Allergy Clin Immunol 126: 581-589. e1-e20, 2010.

17. Malmhäll C, Alawieh S, Lu Y, Sjöstrand M, Bossios A, Eldh $M$ and Rådinger M: MicroRNA-155 is essential for $\mathrm{T}(\mathrm{H}) 2$-mediated allergen-induced eosinophilic inflammation in the lung. J Allergy Clin Immunol 133: 1429-1438.e1-e7, 2014.

18. Zech A, Ayata CK, Pankratz F, Meyer A, Baudiß K, Cicko S, Yegutkin GG, Grundmann S and Idzko M: MicroRNA-155 modulates P2R signaling and Th2 priming of dendritic cells during allergic airway inflammation in mice. Allergy 70: $1121-1129,2015$.

19. Matsukura S, Osakabe Y, Sekiguchi A, Inoue D, Kakiuchi Y, Funaki T, Yamazaki Y, Takayasu H, Tateno H, Kato E, et al: Overexpression of microRNA-155 suppresses chemokine expression induced by Interleukin-13 in BEAS-2B human bronchial epithelial cells. Allergol Int (65 Suppl): S17-S23, 2016.

20. Plank MW, Maltby S, Tay HL, Stewart J, Eyers F, Hansbro PM and Foster PS: MicroRNA expression is altered in an ovalbumin-induced asthma model and targeting miR-155 with antagomirs reveals cellular specificity. PLoS One 10: e144810, 2015.

21. Naldini L, Blömer U, Gallay P, Ory D, Mulligan R, Gage FH, Verma IM and Trono D: In vivo gene delivery and stable transduction of nondividing cells by a lentiviral vector. Science 272: 263-267, 1996.

22. Lee CC, Huang HY and Chiang BL: Lentiviral-mediated GATA-3 RNAi decreases allergic airway inflammation and hyperresponsiveness. Mol Ther 16: 60-65, 2008.

23. Wang A, Wang Z, Cao Y, Cheng S, Chen H, Bunjhoo H, Xie J, Wang C, Xu Y and Xiong W: CCL2/CCR2-dependent recruitment of Th17 cells but not Tc17 cells to the lung in a murine asthma model. Int Arch Allergy Immunol 166: 52-62, 2015.

24. Chen C, Ridzon DA, Broomer AJ, Zhou Z, Lee DH, Nguyen JT, Barbisin M, Xu NL, Mahuvakar VR, Andersen MR, et al: Real-time quantification of microRNAs by stem-loop RT-PCR. Nucleic Acids Res 33: e179, 2005. 
25. Schmittgen TD and Livak KJ: Analyzing real-time PCR data by the comparative $\mathrm{C}(\mathrm{T})$ method. Nat Protoc 3: 1101-1108, 2008.

26. Kramer EL, Mushaben EM, Pastura PA, Acciani TH, Deutsch GH, Khurana Hershey GK, Korfhagen TR, Hardie WD, Whitsett JA and Le Cras TD: Early growth response-1 suppresses epidermal growth factor receptor-mediated airway hyperresponsiveness and lung remodeling in mice. Am J Respir Cell Mol Biol 41: $415-425,2009$

27. Chen H, Xu X, Teng J, Cheng S, Bunjhoo H, Cao Y, Liu J, Xie J, Wang C, Xu Y and Xiong W: CXCR4 inhibitor attenuates allergen-induced lung inflammation by down-regulating MMP-9 and ERK1/2. Int J Clin Exp Pathol 8 : 6700-6707, 2015.

28. Chen H, Cheng S, Wang A, Bunjhoo H, Cao Y, Xie J, Wang C, $\mathrm{Xu} \mathrm{Y}$ and Xiong W: IL-21 does not involve in OVA-induced airway remodeling and chronic airway inflammation. Int J Clin Exp Med 8: 10640-10645, 2015.

29. Lu TX, Munitz A and Rothenberg ME: MicroRNA-21 is up-regulated in allergic airway inflammation and regulates IL-12p35 expression. J Immunol 182 4994-5002, 2009.

30. Sharma A, Kumar M, Ahmad T, Mabalirajan U, Aich J, Agrawal A and Ghosh B: Antagonism of mmu-mir-106a attenuates asthma features in allergic murine model. J Appl Physiol (1985) 113: 459-464, 2012.

31. Qin HB, Xu B, Mei JJ, Li D, Liu JJ, Zhao DY and Liu F: Inhibition of miRNA-221 suppresses the airway inflammation in asthma. Inflammation 35: 1595-1599, 2012

32. Garbacki N, Di Valentin E, Huynh-Thu VA, Geurts P, Irrthum A, Crahay C, Arnould T, Deroanne C, Piette J, Cataldo D and Colige A: MicroRNAs profiling in murine models of acute and chronic asthma: A relationship with mRNAs targets. PLoS One 6: e16509, 2011

33. Comer BS, Camoretti-Mercado B, Kogut PC, Halayko AJ, Solway J and Gerthoffer WT: Cyclooxygenase-2 and microRNA-155 expression are elevated in asthmatic airway smooth muscle cells. Am J Respir Cell Mol Biol 52: 438-447, 2015.

34. Kuo YC, Li YS, Zhou J, Shih YR, Miller M, Broide D, Lee OK and Chien S: Human mesenchymal stem cells suppress the stretch-induced inflammatory miR-155 and cytokines in bronchial epithelial cells. PLoS One 8 . e71342, 2013
35. Busse WW: The relationship of airway hyperresponsiveness and airway inflammation: Airway hyperresponsiveness in asthma: Its measurement and clinical significance. Chest 138 (2 Suppl): 4S-10S, 2010

36. Vignola AM, Mirabella F, Costanzo G, Di Giorgi R, Gjomarkaj M, Bellia V and Bonsignore G: Airway remodeling in asthma. Chest 123 (3 Suppl): 417S-422S, 2003.

37. Gao JM, Cai F, Peng M, Ma Y and Wang B: Montelukast improves air trapping, not airway remodeling, in patients with moderate-to-severe asthma: A pilot study. Chin Med J (Engl) 126: 2229-2234, 2013

38. White SR and Dorscheid DR: Corticosteroid-induced apoptosis of airway epithelium: A potential mechanism for chronic airway epithelial damage in asthma. Chest 122 (6 Suppl): 278S-284S, 2002.

39. Meister G, Landthaler M, Dorsett $Y$ and Tuschl T: Sequence-specific inhibition of microRNA- and siRNA-induced RNA silencing. RNA 10: 544-550, 2004.

40. Abbas-Terki T, Blanco-Bose W, Déglon N, Pralong W and Aebischer P: Lentiviral-mediated RNA interference. Hum Gene Ther 13: 2197-2201, 2002.

41. Matta H, Hozayev B, Tomar R, Chugh P and Chaudhary PM: Use of lentiviral vectors for delivery of small interfering RNA. Cancer Biol Ther 2: 206-210, 2003.

42. Xiao C and Rajewsky K: MicroRNA control in the immune system: Basic principles. Cell 136: 26-36, 2009.

43. Hoefig KP and Heissmeyer V: MicroRNAs grow up in the immune system. Curr Opin Immunol 20: 281-287, 2008

44. O'Connell RM, Rao DS, Chaudhuri AA and Baltimore D: Physiological and pathological roles for microRNAs in the immune system. Nat Rev Immunol 10: 111-122, 2010.

45. Teng G and Papavasiliou FN: Shhh! silencing by microRNA-155. Philos Trans R Soc Lond B Biol Sci 364: 631-637, 2009. 